\title{
Activated Protein C Enhances Cell Motility of Endothelial Cells and MDA-MB-231 Breast Cancer Cells by Intracellular Signal Transduction
}

\author{
Mark W. Gramling ${ }^{1, \ddagger}$, Lea M. Beaulieu ${ }^{1,4,{ }^{*}, \ddagger}$, and Frank C. Church ${ }^{1,2,3,4}$ \\ ${ }^{1}$ Department of Pathology and Laboratory Medicine, The University of North Carolina at Chapel Hill, \\ School of Medicine, Chapel Hill, NC 27599-7035 \\ 2Department of Pharmacology, The University of North Carolina at Chapel Hill, School of Medicine, \\ Chapel Hill, NC 27599-7035 \\ ${ }^{3}$ Department of Medicine, The University of North Carolina at Chapel Hill, School of Medicine, \\ Chapel Hill, NC 27599-7035 \\ ${ }^{4}$ UNC McAllister Heart Institute, The University of North Carolina at Chapel Hill, School of Medicine, \\ Chapel Hill, NC 27599-7035
}

\begin{abstract}
Activated protein C (APC), an anticoagulant serine protease, has been shown to have non-hemostatic functions related to inflammation, cell survival, and cell migration. In this study we investigate the mechanism by which APC promotes angiogenesis and breast cancer invasion using ex vivo and in vitro methods. When proteolytically active, APC promotes cell motility/invasion and tube formation of endothelial cells. Ex vivo aortic ring assays verify the role of APC in promoting angiogenesis, which was determined to be dependent on EGFR and MMP activation. Given the capacity of APC to promote angiogenesis and the importance of this process in cancer pathology, we investigated whether the mechanisms by which APC promotes angiogenesis can also promote motility and invasion in the MDA-MB-231 breast cancer cell line. Our results indicate that, extracellularly, APC engages EPCR, PAR-1, and EGFR in order to increase the invasiveness of MDA-MB-231 cells. APC activation of matrix metalloprotease (MMP) -2 and/or -9 is necessary but not sufficient to increase invasion, and APC does not utilize the endogenous plasminogen activation system to increase invasion. Intracellularly, APC activates ERK, Akt, and NFkB, but not the JNK pathway to promote MDA-MB-231 cell motility. Similar to the hemostatic protease thrombin, APC has the ability to enhance both endothelial cell motility/angiogenesis and breast cancer cell migration.
\end{abstract}

\section{Keywords}

Activated Protein C; EPCR; PAR-1; EGFR; migration-invasion; angiogenesis; aortic rings

(c) 2009 Elsevier Inc. All rights reserved.

Address editorial correspondence (and reprint requests) to: Frank C. Church, Ph.D. University of North Carolina-Chapel Hill, 932 Mary Ellen Jones Building, CB\# 7035, Chapel Hill, NC, 27599-7035, Tel: 919-966-3313, Fax: 919-966-7639, fchurch@email.unc.edu. *Current Address: Whitaker Cardiovascular Institute, Boston University School of Medicine, 700 Albany St W533, Boston, MA 02118-2526

\#These authors contributed equally to this work.

Publisher's Disclaimer: This is a PDF file of an unedited manuscript that has been accepted for publication. As a service to our customers we are providing this early version of the manuscript. The manuscript will undergo copyediting, typesetting, and review of the resulting proof before it is published in its final citable form. Please note that during the production process errors may be discovered which could affect the content, and all legal disclaimers that apply to the journal pertain. 


\section{INTRODUCTION}

Activated protein $\mathrm{C}$ (APC), a liver-derived serine protease [1] has known functions in vivo as an anticoagulant. Zymogen protein $\mathrm{C}$ (PC) is localized to the endothelium by binding to endothelial cell protein C receptor (EPCR) [2]. Thrombin bound to the endothelial cell surface by thrombomodulin (TM) [2,3], cleaves PC into its active form. Along the periphery of the clot, APC proteolytically inactivates factors Va and VIIIa [4,5] in the presence of protein $\mathrm{S}$ (PS) [6,7]. In humans, severe thrombophilia occurs with deficiencies in PC or PS and with a mutation in factor Va that prevents its inactivation by APC, known as Factor V Leiden [8]. Recently, in the Recombinant Human Activated Protein C Worldwide Evaluation in Severe Sepsis (PROWESS) Study, patients diagnosed with sepsis and acute organ dysfunction were treated with recombinant human APC, resulting in a mortality reduction of 19.4\% [9].

APC has a role in regulating migration of various cell types. Kobayashi, et al. [10] originally reported APC promotes invasion of ovarian cancer and choriocarcinoma cells only in the presence of the serine protease inhibitor (serpin) plasminogen activator inhibitor-1 (PAI-1). They suggest APC forms a stable complex with PAI-1, thereby removing a potent inhibitor of urokinase plasminogen activator (uPA) from the system [10]. uPA directly activates matrix metalloprotease (MMP)-2 and uPA can also regulate MMP-9 expression [11-13], both of which are zinc-dependent proteases that degrade the ECM. Plasmin, which is activated directly by uPA, can also activate both MMP-9 [14] and MMP-2 [15]. Previously, APC has been shown to activate MMP-2 from an intermediate to a fully active protease [16-19]. In vitro cell culture assays with keratinocytes have shown that APC promotes cell migration by increasing both the expression and activation of MMP-2 [19]. In vivo, APC promotes angiogenesis and wound healing by reducing inflammation, increasing VEGF expression, and increasing MMP-2 [17].

Beyond its potential for manipulating the activation of MMP's, APC has also been implicated in intracellular signal transduction pathways, which alter proliferation and migration. APC has been shown to increase endothelial cell proliferation and in vivo angiogenesis in a concentration dependent manner through activation of the mitogen activated protein kinase (MAPK), phosphatidylinositol-3 kinase (PI3K), and endothelial nitric oxide synthase (eNOS) pathways [20]. It has also been shown that APC, in the presence of caveolin-1, activates Rac1 through PAR-1 to promote protective barrier signaling in immortalized HUVEC [21]. There is relatively limited data on APC induced signal transduction in cell types outside of endothelial cells. However, it has been shown that in epidermal keratinocytes, APC can stimulate the MAPK pathway via transactivation of the epidermal growth factor receptor (EGFR) [22].

Our primary objectives in this study were to (1) confirm the role of APC in promoting angiogenesis using both in vitro and ex vivo models; (2) explore the role of MMP and EGFR activation in APC stimulated angiogenesis; and (3) examine the mechanism that accounts for our previous finding that APC can promote motility in MDA-MB-231 breast cancer cells [23]. The results described here provide evidence that MMP and EGFR activation are necessary for APC induced angiogenesis. Furthermore, the results indicate that APC promotes breast cancer cell motility and invasion through pathways similar to those previously reported for endothelial cells and keratinocytes, but different from the mechanism reported for other cancer cells. Specifically, this mechanism involves binding to EPCR, activation of both PAR-1 and EGFR to promote intracellular signaling through MAPK and PI3K pathways, and extracellular interactions with MMP-2 and -9 to support ECM degradation. 


\section{MATERIAL AND METHODS}

\section{Cell Culture}

Human umbilical vein endothelial cells (HUVEC), obtained from Cambrex, were grown according to manufacturer's specifications. Cells were grown in endothelial cell basal media with $2 \%$ fetal bovine serum (FBS), bovine brain extract (BBE) with heparin, GA-1000, human epidermal growth factor ( $\mathrm{hEGF}$ ), and hydrocortisone (Cambrex). Assays were performed using the MDA-MB-231 breast cancer cell line obtained from the University of North Carolina Chapel Hill Tissue Culture Facility. These cells were maintained in Minimum Essential Media (MEM; Gibco) with 10\% FBS (Sigma), 1\% sodium pyruvate (Gibco), and 1\% antibiotic/ antimycotic (Gibco). All cells were cultured in an incubator at $37^{\circ} \mathrm{C}, 5 \% \mathrm{CO}_{2}$.

\section{Immunofluorescence}

In the murine ex vivo aortic ring assays, after 5 days in culture, aortic sections were fixed in $4 \%$ paraformaldehyde in 1 X PBS for 30 minutes on ice. After 2 washes in 1 X PBS, the sections were permeabilized with $0.5 \%$ Triton X-100 in $1 \mathrm{X}$ PBS for 15 minutes on ice. To block any reactive aldehyde groups, the sections were treated with $0.2 \mathrm{M}$ glycine for 20 minutes on ice and washed. Each section was blocked overnight in 10\% goat serum in 1X PBS, $1 \%$ BSA at $4{ }^{\circ} \mathrm{C}$. The following day each section was washed in $1 \mathrm{X}$ PBS and then treated with a rabbit polyclonal anti-von Willebrand factor (vWF) antibody (1:50 in 1X PBS, 1\% BSA; Dako) or normal rabbit serum, overnight at $4^{\circ} \mathrm{C}$. The next day, each aortic section was washed 5 times with $1 \mathrm{X}$ PBS, $1 \% \mathrm{BSA}$, then allowed to sit in this wash solution overnight at $4^{\circ} \mathrm{C}$. Each section was treated with goat $\mathrm{F}\left(\mathrm{ab}^{\prime}\right)_{2}$ anti-rabbit IgG conjugated to Lissamine Rhodamine-B (1:50 in $1 \mathrm{X}$ PBS, $1 \% \mathrm{BSA}$; BioSource International), covered, and stored overnight at $4^{\circ} \mathrm{C}$. Each aortic section was washed 5 times with $1 \mathrm{X}$ PBS and stored in $1 \mathrm{X} \mathrm{PBS}$, covered at $4^{\circ} \mathrm{C}$, until photographs could be taken with the Olympus IMT2 Inverted Flourescence Microscopy using a TRITC filter.

For experiments with MDA-MB-231 cells, cells grown to form a confluent monolayer in 2chambered slides (Lab Tek II by Nunc) were fixed and stained as previously described [23] without permeabilization. Cells were blocked in $10 \%$ goat serum in $1 \mathrm{X}$ PBS, $1 \%$ BSA for 30 minutes and then treated with mouse EGFR antibody (Upstate) or serum mouse IgG $(5 \mu \mathrm{g} / \mathrm{mL}$; Sigma) for $1 \mathrm{~h}$. After multiple washes in 1X PBS, 1\% BSA, cells were treated with sheep antimouse $\operatorname{IgG~F}\left(\mathrm{ab}^{\prime}\right)_{2}$ fragment-R-phycoerythrin antibody (1:20; in $1 \mathrm{X}$ PBS, $1 \% \mathrm{BSA}$ ) for 1 hour. Cells were then washed multiple times in $1 \mathrm{X}$ PBS and stored in $1 \mathrm{X}$ PBS at $4^{\circ} \mathrm{C}$. Photographs were taken with an Olympus DP70 Microscope Digital Camera with DP70-BSW Software using an Olympus BX51WI fluorescent microscope with a TRITC filter. Photographs were taken at a 200X magnification with the same exposure time.

\section{Tube Formation Assay}

In a 24-well plate, wells were coated with Growth Factor-Reduced Matrigel (BD Biosciences) and incubated for $1 \mathrm{~h}$ at $37^{\circ} \mathrm{C} .80,000 \mathrm{HUVEC} /$ well were plated with increasing concentrations of APC (0-10 $\mu \mathrm{g} / \mathrm{mL}$; Xigris ${ }^{\circledR}$; Eli Lilly and Co.), PC (10 $\mu \mathrm{g} / \mathrm{mL}$ Hematologic Technology), APC-DEGR (10 $\mu \mathrm{g} / \mathrm{mL}$ Hematologic Technology), or VEGF (100 ng/mL R\&D Systems) and incubated at $37^{\circ} \mathrm{C}$ for $18 \mathrm{~h}$. Photographs were taken at 6,12, and $18 \mathrm{~h}$ using Adobe Photoshop and a Kodak DC290 Digital Camera mounted on an inverted microscope. The number of tubelike structures (defined at a structure no more than 3 cells wide with junction points on each end) were counted in 4-100X views. 


\section{Murine Ex Vivo Aortic Ring Assay}

Wildtype C57BL/6 (Charles River) mice were maintained by the Veterinary Staff of the University of North Carolina at Chapel Hill Department of Laboratory Animal Medicine and all mouse protocols were reviewed and approved by the University's Institutional Animal Care and Use Committee (IACUC).

Based on previous work [24], male and female mice, at varying ages, were anesthetized with $1.25 \%$ tribromethanol $(0.2 \mathrm{~mL} / 10 \mathrm{~g})$ and monitored by toe reflex response and respiratory rate. Once properly anesthetized, an incision was made midline and the organs were removed to expose the aorta from the heart to the renal arterial branch point. The aorta was dissected from the heart to the split for the renal arteries. The dissected aorta were placed in a $100 \mathrm{~mm}$ dish containing Dulbecco's Modified Eagle Media (DMEM; Gibco) with $1 \%$ antibiotic/antimycotic (Gibco) and cleaned of connective tissue and fat. Cleaned aortas were then sectioned into 1-2 $\mathrm{mm}$ pieces and placed into a new $100 \mathrm{~mm}$ dish containing DMEM with $1 \%$ antibiotic/ antimycotic and allowed to incubate for approximately $1 \mathrm{~h}$ at $37^{\circ} \mathrm{C}, 5 \% \mathrm{CO}_{2}$ until implantation. In a 48-well plate, $200 \mu \mathrm{L}$ of Growth Factor-Reduced Matrigel was plated in each well and placed in an incubator at $37^{\circ} \mathrm{C}, 5 \% \mathrm{CO}_{2}$ for 10 minutes. One aortic section per well was placed on top of the gelatinized Matrigel, covered with an additional $200 \mu \mathrm{L}$ of Growth Factor-

Reduced Matrigel, and incubated for 10 minutes. $200 \mu \mathrm{L}$ of endothelial basal media with $2 \%$ FBS, BBE with heparin, GA-1000, hEGF, and hydrocortisone (Cambrex) was added to each well with either no additional treatment (negative control), $100 \mathrm{ng} / \mathrm{mL}$ VEGF (positive control), or increasing concentrations of APC $(0-10 \mu \mathrm{g} / \mathrm{mL})$. To eliminate any effects of thrombin on sprout formation, $50 \mathrm{nM}$ of hirudin was added to the aortic sections with or without APC (10 $\mu \mathrm{g} / \mathrm{mL}$ ). To determine if the active form of APC was needed to increase sprout formation, aortic sections were also treated with PC $(10 \mu \mathrm{g} / \mathrm{mL})$ with or without hirudin $(50 \mathrm{nM})$ or APCDEGR $(10 \mu \mathrm{g} / \mathrm{mL})$. In studies looking at EGFR, PI3K, and MMPs, pharmacological inhibitors, AG 1478 (10 $\mu \mathrm{M}$;Biomol) [25], LY 294002 (10 $\mu \mathrm{g} / \mathrm{mL}$; Biomol) [26], and GM 6001 (10 $\mu \mathrm{g} /$ $\mathrm{mL}$;Biomol) [27], respectively, were added to the aortic sections 30 minutes prior to the addition of APC $(10 \mu \mathrm{g} / \mathrm{mL})$. Every $24 \mathrm{~h}$ for 5 days, media from each well was removed and replaced with fresh conditioned media. On days 3-5, the number of sprouts extending form the periphery of the aortic sections was counted and digital photographs were taken using Adobe Photoshop and a Kodak DC290 Digital Camera mounted on an inverted microscope.

\section{Western Blots}

$25 \mu \mathrm{g}$ total protein from cell lysates created in complete RIPA buffer were run on $12 \%$ SDSPAGE gels and transferred onto PVDF (Millipore). Cell lysates were probed for P-ERK1/2 (Santa Cruz Biotechnology), total ERK2 (Santa Cruz Biotechnology), P-Akt (Cell Signaling), total Akt (Cell Signaling), P-c JUN (Cell Signaling), total c JUN (Cell Signaling), IкB- $\alpha$ (Cell Signaling), MMP-2/9 (Chemicon), tubulin (Sigma), and actin (Santa Cruz Biotechnology).

\section{3-(4,5-Dimethyl-2-thiazolyl)-2,5-diphenyl-2H-tetrazolium bromide (MTT) Assays Using Epidermal Growth Factor}

MDA-MB-231 cell viability was measured using a MTT assay. 10,000 cells/well were plated in a 96-well plate, incubated overnight at $37^{\circ} \mathrm{C}, 5 \% \mathrm{CO}_{2}$. Cells were treated with SFM containing $1 \%$ sodium pyruvate, $1 \%$ antibiotic/antimycotic with mouse EGFR antibody or mouse serum IgG for $15 \mathrm{~min}$ followed by the addition of recombinant hEGF ( $1 \mathrm{nM}$ final concentration; Invitrogen). After a $48 \mathrm{~h}$ incubation, cells were treated with SFM with 3-(4,5Dimethyl-2-thiazolyl)-2,5-diphenyl-2H-tetrazolium bromide (MTT) $(0.5 \mathrm{mg} / \mathrm{mL}$; Sigma) for $2 \mathrm{~h}$. DMSO was added to each well to dissolve the formazan crystals formed by living cells for $15 \mathrm{~min}$ at $37^{\circ} \mathrm{C}, 5 \% \mathrm{CO}_{2}$. The absorbance of each well was read at $560 \mathrm{~nm}$. 


\section{Transwell Invasion and Chemotaxis Assays}

Migration was evaluated as previously described using the transwell invasion and chemotaxis assays [23,28,29]. For endothelial cells, the chemotactic agent, $1 \mathrm{ng} / \mathrm{mL}$ VEGF (R\&D Systems) in culture media was added to the well. 50,000 cells/insert were treated with increasing concentrations of APC (0-10 $\mu \mathrm{g} / \mathrm{mL}$; Xigris ${ }^{\circledR}$; Eli Lilly and Co.) in culture media and added to the insert. Endothelial cell invasion and chemtoxis assays were both incubated for $24 \mathrm{hr}$. MDA-MB-231 cells, also plated at 50,000 cells/insert, migrated towards 10\% FBS (the chemotactic agent) containing media. Chemotaxis assays for the breast cancer cells were incubated for $12 \mathrm{~h}$, while the invasion assays were incubated for $24 \mathrm{~h}$. All experiments were done at $37^{\circ} \mathrm{C}, 5 \% \mathrm{CO}_{2}$. Blocking antibodies used to study receptors potentially bound by APC were plated with the cells and allowed to incubate at room temperature for $15 \mathrm{~min}$ prior to the addition of APC. These antibodies include mouse EPCR antibody (JNK 1494; provided by Dr. Charles T. Esmon, OMRF, Oklahoma, OK), mouse PAR-1 antibodies (atap2 and wede15; Zymed and Immunotech, respectively), mouse EGFR antibody (Upstate), and mouse serum $\operatorname{IgG}$ (Sigma). Blocking antibodies used to study the role of the plasminogen activation system, including goat PAI-1 antibody (American Diagnostica), mouse uPA antibody (American Diagnostica), and serum mouse or goat IgG (Sigma), were plated with the cells and allowed to incubate at room temperature for $1 \mathrm{~h}$ prior to the addition of APC. Amiloride, an inhibitor of uPA, was also preincubated for $1 \mathrm{~h}$ with the cells. Pharmacological inhibitors that block specific signaling pathways were plated with the cells and allowed to preincubate at room temperature for $1 \mathrm{~h}$. These compounds include PD 98059 (Biomol), LY 294002 (Biomol), and SP 600125 (Biomol). Finally, inhibitors for MMPs, GM 6001 (Biomol) and SB-3CT (Biomol) were plated with the cells and preincubated for 15 min prior to the addition of APC. To determine if selective inhibitors of MMPs were affecting APC activity levels, conditioned media from the transwell assays were tested for APC activity using an APC-specific chromogenic substrate (final concentration of $0.15 \mathrm{mM}$; Centerchem) as previously described [23].

\section{Quantitative PCR}

Serum starved MDA-MB-231 cells at $\sim 85 \%$ confluence were serum starved for $24 \mathrm{~h}$, then treated with SFM containing increasing concentrations of APC $(0,100 \mathrm{ng} / \mathrm{ml}, 1 \mu \mathrm{g} / \mathrm{ml}, 10 \mu \mathrm{g} /$ $\mathrm{ml}$ ). After isolation through Trizol (Invitrogen), RNA was reverse transcribed using M-MLV reverse transcriptase (Invitrogen). Quantitative real-time PCR was performed using SYBR Green Dye (Applied Biosystems) and the following protocol: 5 minute initial denaturation step at $95^{\circ} \mathrm{C}$, followed by 40 cycles of $95^{\circ} \mathrm{C}$ for $20-\mathrm{s}, 55^{\circ} \mathrm{C}$ for $1 \mathrm{~min}$, and $68^{\circ} \mathrm{C}$ for 30 -s. Using $\beta$ actin as a loading control, results were interpreted by the relative quantity method $(\Delta \Delta \mathrm{Ct})$ as described [30]. Primer sequences were: MMP-2 sense 5'-ATAACCTGGATGCCGTCGT-3', MMP-2 anti-sense 5'-AGGCACCCTTGAAGAAGTAGC-3', MMP-9 sense 5' -

CGGTGATTGACGACGCCTTT-3', MMP-9 anti-sense 5'-

ACCAAACTGGATGACGATGTCTG-3', $\beta$-actin sense 5'-

ATCATGTTTGAGACCTTCAA-3', and $\beta$-actin anti-sense 5'-

CATCTCTTGCTCGAAGTCCA-3'.

\section{Statistical Analysis}

For each transwell experiment, conditions were done in duplicate or triplicate and averaged. Averages of each condition were compared to No Treatment, APC alone, or blocking antibody/ inhibitor alone. Experiments were repeated as indicated in the figure legends and averaged together. Results show the percentages compared to No Treatment, which is set to $100 \%$. Statistical analysis was performed on each comparison - to No Treatment, APC, or blocking antibody/inhibitor - using a one sample T-test with a normal distribution, a theoretical mean of 100 , and significance of $\mathrm{p}<0.05$. For quantitative real time PCR, $\Delta \Delta \mathrm{Ct}$ values were averaged 
from three independent experiments and compared to a theoretical mean of 1 , also using a one sample T-test, $\mathrm{p}<0.05$.

\section{RESULTS}

\section{APC Promotes Endothelial Cell Motility and Angiogenesis}

Given the previous reports in vivo that APC may directly promote angiogenesis, we were interested in closely examining this phenomenon using an in vitro and ex vivo models in parallel. For the in vitro model, HUVEC were treated with increasing concentrations of APC in the transwell chemotaxis and invasion assays, with VEGF $(1 \mathrm{ng} / \mathrm{mL})$ as the chemotactic agent. As seen in Figure 1A, APC optimally promoted invasion at $0.1 \mu \mathrm{g} / \mathrm{mL}$ and chemotaxis at $0.5 \mu \mathrm{g} / \mathrm{mL}$. Notably, this APC-promoted increase in invasion and chemotaxis occurs at concentrations that are below the physiological level of PC found in plasma $(\sim 4 \mu \mathrm{g} / \mathrm{mL})$. The highest concentration of APC $(10 \mu \mathrm{g} / \mathrm{mL})$ used in this assay actually reduced both invasion and chemotaxis of HUVEC compared to No Treatment. These results suggest that, in these experimental conditions, HUVEC invasion and chemotaxis are increased at a physiologically relevant concentration of APC, but are inhibited at much higher levels.

HUVEC plated onto growth factor-reduced Matrigel will form a network of tube-like structures, defined as 1-3 cells wide with junction points at both ends (as seen in Figure 1B, No Treatment). Upon the addition of a pro-angiogenic factor, VEGF, HUVEC will form an increased number of stable tube-like structures (Figure 1B, VEGF treatment). As with the transwell assays, treatment with increasing concentrations of APC $(0-10 \mu \mathrm{g} / \mathrm{mL})$ increases the formation of tube-like structures by $130 \%$ at an optimal concentration $(1 \mu \mathrm{g} / \mathrm{mL})$ and at an optimal timepoint (12 h) (Figure 1C), similar to the effects of VEGF (data not shown).

To determine if the effects of APC on tube formation are due to its proteolytic activity, HUVEC were also treated with 2 inactive forms of APC, the zymogen PC $(1 \mu \mathrm{g} / \mathrm{mL})$ and the chemically inactive protease, APC-DEGR $(1 \mu \mathrm{g} / \mathrm{mL})$. At $12 \mathrm{~h}$, only the active protease is able to significantly increase the formation of tube-like structures by $135 \%$ compared to No Treatment (Figure 1B and C). These results suggest that APC must proteolytically cleave another protease or receptors in order to increase the formation of tube-like structures.

For the ex vivo model we utilized the murine aortic ring assay. In this assay, murine aortic sections produce sprouts composed of endothelial cells along the periphery of the vessel that will lengthen and branch over time. Upon treatment with a pro-angiogenic factor, such as VEGF, there will be an increase in the number of endothelial cell sprouts, the length of the sprouts, and their ability to survive in culture. As seen in Figure 1D, increasing concentrations of APC $(0-10 \mu \mathrm{g} / \mathrm{mL})$ increased sprout formation around each section compared to No Treatment. Only the highest concentration of APC $(10 \mu \mathrm{g} / \mathrm{mL})$ was able to significantly increase the amount (300-400\% compared to No Treatment) of sprouts earlier (Day 3) than VEGF (Day 4). Immunofluorescence staining for vWF, an endothelial cell-specific marker, was done to verify that the cells responding to APC treatment were in fact endothelial cells. As seen in Figure 1E, both VEGF and APC were able to increase sprout formation of vWFpositive endothelial cells. Therefore, APC increased the formation of endothelial cell sprouts on murine aortic rings similar to the pro-angiogenic factor, VEGF.

To determine if the effects shown with APC are specific for this protease and not another serine protease, thrombin, aortic sections were also treated with hirudin $(50 \mathrm{nM})$, a potent and specific inhibitor of thrombin that has been previously shown to inhibit thrombin-promoted cell migration [23]. As seen in Figure 1F, at day 4, APC increases sprout formation 300-400\% compared to No Treatment, in the presence and absence of hirudin. The effects of hirudin alone are not significant. Further, PC, PC/hirudin, and APC-DEGR did not significantly increase 
sprout formation over No Treatment (Figure 1F). Therefore, APC promotes endothelial sprout formation, independent of any thrombin present in this assay.

\section{APC promotes angiogenesis through MMP and EGFR activation}

Having shown APC promotes angiogenesis in both our in vitro and ex vivo models, we examined whether the response is due to activation of MMP and EGFR, as it has been reported both are involved in APC mediated motility and proliferation in keratinocytes [19]. To determine if MMPs are important in APC-promoted angiogenesis, the general MMP inhibitor, GM 6001, was used in the ex vivo murine aortic ring assay. Compared to No Treatment, there was no effect of GM 6001 on sprout formation at day 4 (Figure 2A). APC alone increases sprout formation $400 \%$ compared to No Treatment. When the aortic sections were treated with APC and GM 6001, there is no longer an increase over No Treatment as seen with APC alone, suggesting GM 6001 blocks the effect of APC on endothelial cell sprout formation (Figure $2 A)$. Sprouts that form around the periphery of the aortic section treated with GM 6001 and APC are neither as numerous, nor as long as the ones that form with APC treatment alone. Taken together, these results imply that APC promotes angiogenesis through MMPs.

To determine if EGFR activation is involved in APC promoted angiogenesis, murine aortic rings were treated with a chemical inhibitor, AG 1478, that blocks ligand binding to EGFR. As seen in Figure 2B, at day 4, AG 1478 alone reduces the formation of sprouts because of the importance of this receptor in angiogenesis. If EGFR is not important to the mechanism utilized by APC to increase endothelial cell sprout formation, then APC treatment with the inhibitor would be expected to have increased sprout formation relative to inhibitor treatment alone. However, in the presence of AG 1478, APC is unable to increase endothelial cell sprout formation relative to the number of sprouts with AG 1478 alone. Therefore, EGFR is involved in the mechanism utilized by APC to increase angiogenesis.

\section{APC Promotes MDA-MB-231 Breast Cancer Cell Invasion through EPCR and PAR-1}

It has been well documented that APC's ability to promote angiogenesis and alter signaling is dependent on binding to cell surface receptors EPCR and PAR-1. Previously, we showed that APC binds to both EPCR and PAR-1 to increase chemotaxis of the MDA-MB-231 breast cancer cell line [23]. To further examine the role of these receptors in the overall motility of breast cancer cells, we studied the effects of blocking EPCR and PAR-1 in the transwell invasion assay. Addition of a blocking antibody to EPCR abrogated the effects of APC on invasion compared to APC treatment alone (Figure 3A). The PAR-1 blocking antibodies wede 15 and atap2 also hindered the effects of APC, reducing the level of invasion back to No Treatment (Figure 3B).

\section{APC Promotes MDA-MB-231 Cell Chemotaxis through MAPK and PI3K/Akt Activation}

Based on previous work that suggested APC is capable of activating the MAPK and PI3K/Akt pathways in other cell types, we investigated whether APC can activate these pathways in the MDA-MB-231 cells and the impact of these pathways on invasion. First, cells were treated with increasing concentrations of APC. As shown in Figure 4A, at all concentrations of APC used, APC activated PI3K as evidenced by increased phosphorylation of Akt. Furthermore, MAPK activity increased in a dose dependent response to APC as evidence by increased phosphorylation of ERK1/2. We further studied the MDA-MB-231 cells using the transwell assays to determine if PI3K and MAPK activity had an impact on APC-promoted cell chemotaxis (Figure 4B). LY 294002 was used to inhibit PI3K activity and reduce phosphorylation of Akt. LY 294002 completely reduced P-Akt levels (Figure 4C) at $50 \mu \mathrm{M}$ without affecting cell viability. In the transwell chemotaxis assay, LY 294002 caused a loss of chemotaxis (Figure 4B), as expected since this is an important signaling pathway for cell migration. If this pathway was not activated by APC, we would expect that combined APC 
and LY 294002 treatment would be increased over LY 294002 alone. However, APC and LY 294002 treatment was the same as LY 294002 treatment alone (Figure 4B), indicating that APC promotes cell migration through a PI3K dependent pathway.

The PD 98059 compound was used to inhibit MEK1/2 phosphorylation of ERK1/2 (Figure $4 \mathrm{E})$. The $20 \mu \mathrm{M}$ concentration was used in the transwell assay as it did not inhibit cell survival as seen with higher concentrations. Because the MAPK pathway is an important signaling pathway for cell migration, treatment with the PD 98059 compound alone reduced chemotaxis (Figure 4D). Combined APC and PD 98059 treatment was reduced to the same level as PD 98059 treatment alone; suggesting that APC promoted cell migration also depends on MAPK activity.

Notably, chemotaxis assays were also performed using a c JUN inhibitor, SP 600125, which inhibits JNK phosphorylation. Despite the documented links between the JNK pathway and EGFR activation [31] and PAR-1 activation [32], treatment with SP 600125 did not inhibit APC induced chemotaxis (data not shown), suggesting that the JNK pathway is not involved in APC mediated motility.

\section{APC Promotes MDA-MB-231Cell Motility through EGFR Activation}

Having established that EGFR activation is involved in the ability of APC to promote chemotaxis and angiogenesis in endothelial cells, we investigated whether EGFR activation is also involved in the chemotaxis and invasion of MDA-MB-231 breast cancer cells in response to APC. We verified through immunofluorescence the expression of EGFR on the cell surface (Figure 5A). To confirm this receptor was functional, MDA-MB-231 cells were treated with EGF and cellular viability was measured using a MTT assay. MDA-MB-231 cell viability increased in the presence of EGF or EGF and mIgG compared to No Treatment (Figure 5B). This increase was abrogated by a blocking antibody to EGFR $(20 \mu \mathrm{g} / \mathrm{mL})$. In the transwell invasion and chemotaxis assay, APC increased invasion approximately $200 \%$ over No Treatment and chemotaxis approximately $150 \%$ (Figure 5C). Treatment with EGFR blocking antibody alone had no effect on cell migration (Figure 5C). In contrast, the EGFR blocking antibody substantially reduced APC-promoted invasion and chemotaxis of the MDA-MB-231 cells (Figure 5C). These results indicate that in addition to EPCR and PAR-1, a third receptor, EGFR, is involved in the APC-promoted chemotaxis and invasion of the MDA-MB-231 cancer cell line.

\section{APC Promotes MDA-MB-231 Cell Invasion through MMPs}

Having observed that MMPs are involved in APC mediated angiogenesis in our ex vivo aortic ring model, we investigated whether MMPs, specifically MMP-2 and/or MMP-9, are involved in the increased invasion of MDA-MB-231 cells in response to APC. It has previously been suggested that APC may directly activate MMPs or increase MMP expression through NFKB activation [33,34], which could occur downstream of PI3K and MAPK pathways. Our results suggest that despite $\mathrm{NF \kappa B}$ activation, as evidence by degradation of the NFאB inhibitory protein IкB- $\alpha$ [35] (Figure 6A, inset), no statistically significant changes in MMP-2 or MMP-9 RNA occurred in response to APC. Furthermore, we did not see any evidence of increased protein levels of pro-MMP-2/9 or activated MMP-2/9 fragments as measured by immunoblot (data not shown).

Despite the lack of altered expression and activity of MMP-2/9 in response to APC, we reasoned they might still be involved in elevated invasion of MDA-MB-231 cells based on our results with the murine aortic ring assay. First, a broad-spectrum hydroxamate inhibitor of MMPs, GM 6001, was used to determine if MMPs have a role in APC promoted invasion of the MDA-MB-231 cells. As shown in Figure 6B, GM 6001 treatment reduced invasion 
compared to No Treatment in a concentration dependent manner as expected due to the reduction of active proteases that can degrade the ECM. GM 6001 and APC together yielded similar results. Because the GM 6001 MMP inhibitor is a broad-spectrum inhibitor, we also used an inhibitor with specificity for only MMP-2 and -9, SB-3CT, to determine if these MMPs were involved in APC-promoted cell invasion. Invasion was reduced in a concentration dependent manner upon SB-3CT treatment alone as expected (Figure 6C). With SB-3CT and APC treatment, we see a similar trend (Figure 6C). APC activity assays verified that neither GM 6001 nor SB-3CT had an effect on APC activity (data not shown). Combined with the data in Figure 6A, these results imply that MMP activity is necessary for APC induced invasion of MDA-MB-231 cells but that APC does not significantly increase MMP-2/9 activity or expression levels in these cells.

\section{APC Does Not Increase MDA-MB-231 Cell Invasion Through the Plasminogen Activation System}

It was previously hypothesized that APC promotes invasion in ovarian and choriocarcinoma cells by altering the balance between UPA and PAI- 1 to favor uPA proteolytic activity. If APC were to enhance uPA proteolytic activity, it is possible that the observed changes in PI3K, MAPK, and EGFR activity associated with APC treatment could be mostly due to uPA. We therefore examined this hypothesis with the MDA-MB-231 cell line which expresses both uPA and PAI-1. mRNA levels of UPA and PAI-1 were not altered in the presence of APC (data not shown). To determine if APC was altering the level of free uPA in the media, transwell invasion assays were performed with amiloride, a small molecule inhibitor of uPA, and a blocking antibody to uPA with APC. As shown in Figure 7A, APC or APC and DMSO increased invasion of the MDA-MB-231 cells greater than $150 \%$. The amiloride treatment alone reduced invasion to approximately $70 \%$ of No Treatment. This result was expected since uPA was inhibited, reducing the activation of plasminogen and MMPs, which mediate cellular invasion. If uPA was a key component to the mechanism by which APC promoted invasion, then the treatment of APC and amiloride should have the same result as amiloride treatment alone. However, APC still increased invasion of the MDA-MB-231 cells even when uPA was inhibited, indicating that APC promotes cell invasion through a mechanism other than through uPA. APC activity assays verified that APC was not inhibited by amiloride (data not shown). To further confirm that uPA was not involved in the mechanism, a blocking antibody to the active site of uPA was used in the transwell invasion assay (Figure 7B). As was found with amiloride, even in the presence of the uPA-blocking antibody, APC was able to increase cell invasion approximately $150 \%$ compared to No Treatment.

To determine if PAI-1 has a role in APC-promoted increase in invasion, a blocking antibody to PAI-1 was used along with APC in the transwell invasion assays (Figure 7C). In contrast to control goat IgG, the blocking antibody to PAI-1 increased invasion approximately the same amount compared to APC. With limited PAI-1 activity to inhibit uPA, the serine protease can more freely activate proteases that degrade the ECM, such as plasminogen and MMPs.

Interestingly, the addition of APC with the blocking antibody to PAI-1 had an additive effect, increasing invasion further (to approximately $350 \%$ compared to No Treatment) over PAI-1 blocking antibody alone (Figure 1C). These results suggest that APC promotes invasion of the MDA-MB-231 cells by a mechanism distinct from altering the ratio between uPA and PAI-1 that favors uPA proteolytic activity.

\section{DISCUSSION}

In this study, we utilize in vitro and ex vivo models to show that APC can promote angiogenesis in both human and murine endothelial cells through MMP activation and EGFR transactivation - mechanisms that have been proposed for APC mediated motility in other cell types. 
Furthermore, based on previous findings and our own observations, we extended this examination to determine the mechanisms that govern APC promoted motility and invasion in MDA-MB-231 breast cancer cells. In both cell types, we found a common pathway whereby APC promotes angiogenesis and invasion, by activating MMPs and activating EGFR. Using blocking antibodies to EPCR, PAR-1, and EGFR with the breast cancer cells, we found that APC interacts with all three receptors to promote invasion. Our results imply that interaction of these three receptors with APC activates the PI3K and MAPK pathways and that activation of these pathways is necessary for APC to promote migration and invasion.

APC increases HUVEC invasion and migration at optimal concentrations of $0.1 \mu \mathrm{g} / \mathrm{mL}$ and $0.5 \mu \mathrm{g} / \mathrm{mL}$, respectively. Furthermore, APC promotes tube like structures in HUVEC at 0.1 $\mu \mathrm{g} / \mathrm{ml}$. These two concentrations of active protease, $(0.1 \mu \mathrm{g} / \mathrm{ml}=1.8 \mathrm{nM}$ and $0.5 \mu \mathrm{g} / \mathrm{ml}=8.8$ $\mathrm{nM})$ are significantly lower than zymogen PC in plasma $(\sim 4 \mu \mathrm{g} / \mathrm{mL}$ or $\sim 71 \mathrm{nM})$, from which the active protease is derived, and are much less then what have been previously used to show that APC promotes HUVEC proliferation and tube formation [20]. However, these concentrations of APC are similar to those used previously to show that APC can regulate intracellular calcium fluxes [36]. Therefore, the effects of APC described here with HUVEC are likely relevant to physiological concentrations of protein C/APC. By contrast, while higher concentrations of APC were required to detect statistically significant changes in chemotaxis and invasion transwell assays with the MDA-MB-231 cells, $0.1 \mu \mathrm{g} / \mathrm{ml}$ APC was sufficient to activate PI3K and MAPK signaling.

Besides activation of PI3K and MAPK signaling, we also observed activation of NFKB in the MDA-MB-231 cells in response to APC, a finding that contrasts observations in other cell types. Notably, APC has been shown to inhibit endotoxin-induced NFKB nuclear translocation in monocytic cells [37] and APC down-regulates tPA-induced NFKB activity in ischemic endothelial cells, thereby reducing MMP-9 activation [38]. The precise mechanism by which APC could instead activate NFKB in breast cancer cells remains unclear. However, cross-talk between PI3K, MAPK, and NFאB is possible, given the observation that breast cancer cells exhibit a unique positive correlation between PI3K/MAPK signaling and NFKB activation [39-41].

Using the murine ex vivo aortic ring assay, we show that APC increases sprout formation of vWF-positive endothelial cells and that this effect is dependent on MMP and EGFR activation. Notably, this phenomenon was only observed at a higher concentration of APC $(10 \mu \mathrm{g} / \mathrm{ml})$ than the optimal concentration observed for human cells in culture. In one study, the concentration of human APC that effectively reduced the volume of cerebral infarct and increased cerebral blood flow post-onset of stroke in mice was $2 \mathrm{mg} / \mathrm{kg}$ [42]. In contrast, similar studies done with murine APC showed that the same beneficial effects can be seen using 10 times less, $0.2 \mathrm{mg} / \mathrm{kg}[38,43]$. Therefore, it is likely that the requirement for higher concentrations in the murine aortic ring assay is a function of species differences, further suggesting that the effects of APC observed in this study are relevant to physiological concentrations of APC/PC.

Using pharmacological inhibitors in the transwell chemotaxis assays, along with western blot analysis, we show that APC activates the PI3K and MAPK pathways to increase motility of the MDA-MB-231 cells. Based on this study and our results of chemotaxis [23], we suggest that APC is focused at the cell surface through its binding to EPCR and that PAR-1 is subsequently cleaved by APC-bound to EPCR [38]. Furthermore, the results suggest that APC also transactivates EGFR, and that this activity is required to promote motility in the MDAMB-231 cells. 
There are many possible mechanisms whereby PAR-1 and EGFR could work in concert in response to APC to promote motility via activation of PI3K and MAPK signaling. First, APC could bind directly to EGFR, like recently shown for another serine protease, tissue plasminogen activator [44], and directly activate MAPK signaling through Ras [45]. Second, PAR-1 activation mediated by APC cleavage would lead to $\mathrm{G} \alpha$ or $\beta / \gamma$ subunits activating cSrc. c-Src can directly activate PI3K and could also mediate phosphorylation of Tyr 845 on the cytoplasmic tail of EGFR [46], subsequently activating MAPK signaling via Ras. There is proof of principle for this mechanism. Via EPCR and PAR-1, APC has been shown to transactivate another receptor, sphingosine-1-phosphate 1 receptor, which affects vascular permeability of endothelial cells [47]. Third, PAR-1 could possibly activate the TNF-alpha converting enzyme (TACE; ADAM-17), a membrane-bound disintegrin metalloprotease that processes membrane-associated cytokines such as heparin bound-EGF (HB-EGF) or other EGFR-family member ligands to transactivate EGFR $[48,49]$. HB-EGF would bind to the ligand-binding domain of EGFR, leading to the phosphorylation of the receptor and activation of Ras [50-52]. In any mechanism in which Ras is activated, there is a potential for PI3K activation as Ras has been shown to directly activate PI3K [53]. Our results do not favor the direct activation of EGFR by APC, but suggest that APC-EPCR interactions through PAR-1 promote either the transphosphorylation of EGFR (since the EGFR blocking antibody reduced motility in the presence of APC) or by ADAM-17-directed ligand transactivation (since the MMP inhibitor GM 6001 is also known to inhibit ADAM-17).

Within the context of the MDA-MB-231 breast cancer cells, our results suggest a shift away from other mechanistic paradigms that suggest the primary role of APC in motility involves the regulation of pericellular proteolysis. There is prior evidence that APC directly activates MMPs, specifically MMP-2. Through zymography, APC was also shown to activate MMP-2 from the intermediate to fully active form [16,18,54], independent of MT1-MMP [16,54]. Additionally, it has also been shown that solution phase APC [16,54] and APC generated on the cell surface in the presence of thrombin bound to TM can activate MMP-2 [18].

Furthermore, it has been suggested that APC can promote increased expression of MMP-2 $[17,19]$. In our study we found that MMP activity, specifically MMP-2 and MMP-9 activity, is required for APC to promote invasion. However, we did not observe significant changes in either MMP-2 or MMP-9 RNA expression. We also did not observe differences in protein levels of pro-MMP-2/9 or any difference in the amount of active MMP2/9 in culture media in response to APC. These results suggest that while some basal level of MMP-2/9 activity is required to initiate pericellular proteolysis of the extracellular matrix in response to APC, treatment with APC is not significantly increasing MMP expression or activity in the MDAMB-231 cells. It is likely that high levels of uPA as well as signaling cascades that can promote MMP expression, such as MAPK signaling, lead to high basal activity and expression of MMP-2/9 that is not significantly altered by APC treatment.

In a similar regard, our results with the MDA-MB-231 cells also differ from previous studies which suggest that APC promotes motility through inhibition of PAI-1 with subsequent activation of uPA. Kobayashi, et al. [10] found that exogenously added APC increased invasion of cancer cells in vitro by forming a stable complex with the serpin, PAI-1 and thereby APC promotes invasion by increasing uPA activity [10]. However, in our study, blocking uPA with either the chemical inhibitor amiloride or a blocking antibody to its active site did not alter the ability of APC to promote invasion of the MDA-MB-231 breast cancer cells. Moreover, in the presence of a PAI-1 blocking antibody and APC, there was an additive effect to promote invasion. The observation that APC does not promote motility through the plasminogen activator system, taken together with our findings about the role of MMP's in breast cancer cell motility, suggests that APC promotes motility of the MDA-MB-231 cells largely as a consequence of its ability to activate EGFR, MAPK, and PI3K associated signaling cascades. 
In summary, our results show that APC promotes endothelial motility via activation of EGFR and MMP's, both in vitro and ex vivo. With regard to our unique findings with the MDAMB-231 cells, our results show an interesting interdependent nature of the pathways that are activated by APC to increase motility. Blocking of any one of the three involved receptors, (EPCR, PAR-1 or EGFR), or inhibition of MMP-2 and/or MMP-9 results in a loss of the increase in motility promoted by APC. Overall, the effect of APC is coordinated with both intracellular activation of signaling pathways, which promote motility, and with some level of pericellular activation of MMPs, which primes the cells to respond to chemoattractants at an increased rate.

\section{Acknowledgments}

We are grateful to Dr. Charles T. Esmon for providing the anti-EPCR antibody (JNK 1494). We also gratefully acknowledge Lilly Research Laboratories for supplying Xigris ${ }^{\circledR}$ (wild-type recombinant human APC) under study number F1K-US-V016 (to FC Church).

Contract Grant Sponsor- National Institutes of Health F31 NS054590 (to L.M.B.) and T32 HL697668 (to L.M.B.), Thomas and Carolyn Royster Fellowship and Robert H. Wagner Scholarship (to M.W.G.), R01 HL32656 (to F.C.C.) from the NIH, and BCTR0503475 and BCTR45206 from the Susan G. Komen Breast Cancer Foundation (to F.C.C.).

\section{References}

1. Foster D, Davie EW. Characterization of a cDNA coding for human protein C. Proc Natl Acad Sci U S A 1984;81:4766-4770. [PubMed: 6589623]

2. Fukudome K, Kurosawa S, Stearns-Kurosawa DJ, He X, Rezaie AR, Esmon CT. The endothelial cell protein $\mathrm{C}$ receptor. Cell surface expression and direct ligand binding by the soluble receptor. J Biol Chem 1996;271:17491-17498. [PubMed: 8663475]

3. Kisiel W, Canfield WM, Ericsson LH, Davie EW. Anticoagulant properties of bovine plasma protein C following activation by thrombin. Biochemistry 1977;16:5824-5831. [PubMed: 588557]

4. Marlar RA, Kleiss AJ, Griffin JH. Human protein C: inactivation of factors V and VIII in plasma by the activated molecule. Ann N Y Acad Sci 1981;370:303-310. [PubMed: 6791548]

5. Walker FJ, Sexton PW, Esmon CT. The inhibition of blood coagulation by activated protein C through the selective inactivation of activated factor V. Biochim Biophys Acta 1979;571:333-342. [PubMed: 508770]

6. Walker FJ. Regulation of activated protein $\mathrm{C}$ by a new protein. A possible function for bovine protein S. J Biol Chem 1980;255:5521-5524. [PubMed: 6892911]

7. Walker FJ. Regulation of activated protein $\mathrm{C}$ by protein $\mathrm{S}$. The role of phospholipid in factor $\mathrm{Va}$ inactivation. J Biol Chem 1981;256:11128-11131. [PubMed: 6457049]

8. Bertina RM. Factor V Leiden and other coagulation factor mutations affecting thrombotic risk. Clin Chem 1997;43:1678-1683. [PubMed: 9299960]

9. Bernard GR, Vincent JL, Laterre PF, LaRosa SP, Dhainaut JF, Lopez-Rodriguez A, Steingrub JS, Garber GE, Helterbrand JD, Ely EW, Fisher CJ Jr. Efficacy and Safety of Recombinant Human Activated Protein C for Severe Sepsis. N Engl J Med 2001;344:699-709. [PubMed: 11236773]

10. Kobayashi H, Moniwa N, Gotoh J, Sugimura M, Terao T. Role of activated protein C in facilitating basement membrane invasion by tumor cells. Cancer Res 1994;54:261-267. [PubMed: 8261450]

11. Rao NK, Shi GP, Chapman HA. Urokinase receptor is a multifunctional protein: influence of receptor occupancy on macrophage gene expression. J Clin Invest 1995;96:465-474. [PubMed: 7615819]

12. Lakka SS, Gondi CS, Yanamandra N, Dinh DH, Olivero WC, Gujrati M, Rao JS. Synergistic downregulation of urokinase plasminogen activator receptor and matrix metalloproteinase-9 in SNB19 glioblastoma cells efficiently inhibits glioma cell invasion, angiogenesis, and tumor growth. Cancer Res 2003;63:2454-2461. [PubMed: 12750266]

13. Keski-Oja J, Lohi J, Tuuttila A, Tryggvason K, Vartio T. Proteolytic processing of the 72,000-Da type IV collagenase by urokinase plasminogen activator. Exp Cell Res 1992;202:471-476. [PubMed: 1397099] 
14. Makowski GS, Ramsby ML. Binding of latent matrix metalloproteinase 9 to fibrin: activation via a plasmin-dependent pathway. Inflammation 1998;22:287-305. [PubMed: 9604716]

15. Murphy G, Atkinson S, Ward R, Gavrilovic J, Reynolds JJ. The role of plasminogen activators in the regulation of connective tissue metalloproteinases. Ann N Y Acad Sci 1992;667:1-12. [PubMed: 1339240]

16. Jackson C, Nguyen M, Arkell J, Sambrook P. Selective matrix metalloproteinase (MMP) inhibition in rheumatoid arthritis--targetting gelatinase A activation. Inflamm Res 2001;50:183-186. [PubMed: 11392606]

17. Jackson CJ, Xue M, Thompson P, Davey RA, Whitmont K, Smith S, Buisson-Legendre N, Sztynda T, Furphy LJ, Cooper A, Sambrook P, March L. Activated protein C prevents inflammation yet stimulates angiogenesis to promote cutaneous wound healing. Wound Repair Regen 2005;13:284294. [PubMed: 15953048]

18. Pekovich SR, Bock PE, Hoover RL. Thrombin-thrombomodulin activation of protein C facilitates the activation of progelatinase A. FEBS Lett 2001;494:129-132. [PubMed: 11297749]

19. Xue M, Thompson P, Kelso I, Jackson C. Activated protein C stimulates proliferation, migration and wound closure, inhibits apoptosis and upregulates MMP-2 activity in cultured human keratinocytes. Exp Cell Res 2004;299:119-127. [PubMed: 15302579]

20. Uchiba M, Okajima K, Oike Y, Ito Y, Fukudome K, Isobe H, Suda T. Activated protein C induces endothelial cell proliferation by mitogen-activated protein kinase activation in vitro and angiogenesis in vivo. Circ Res 2004;95:34-41. [PubMed: 15166095]

21. Russo A, Soh UJ, Paing MM, Arora P, Trejo J. Caveolae are required for protease-selective signaling by protease-activated receptor-1. Proc Natl Acad Sci U S A 2009;106:6393-6397. [PubMed: 19332793]

22. Xue M, Campbell D, Jackson CJ. Protein C is an autocrine growth factor for human skin keratinocytes. J Biol Chem 2007;282:13610-13616. [PubMed: 17293597]

23. Beaulieu LM, Church FC. Activated protein C promotes breast cancer cell migration through interactions with EPCR and PAR-1. Exp Cell Res 2007;313:677-687. [PubMed: 17254565]

24. Belting M, Dorrell MI, Sandgren S, Aguilar E, Ahamed J, Dorfleutner A, Carmeliet P, Mueller BM, Friedlander M, Ruf W. Regulation of angiogenesis by tissue factor cytoplasmic domain signaling. Nat Med 2004;10:502-509. [PubMed: 15098027]

25. Ullian ME, Webb JG, Chen R, Paul RV, Morinelli TA. Mechanisms of vascular angiotensin II surface receptor regulation by epidermal growth factor. J Cell Physiol 2004;200:451-457. [PubMed: 15254973]

26. Tong Q, Zheng L, Li B, Wang D, Huang C, Matuschak GM, Li D. Hypoxia-induced mitogenic factor enhances angiogenesis by promoting proliferation and migration of endothelial cells. Exp Cell Res 2006;312:3559-3569. [PubMed: 16982054]

27. Enciso JM, Gratzinger D, Camenisch TD, Canosa S, Pinter E, Madri JA. Elevated glucose inhibits VEGF-A-mediated endocardial cushion formation: modulation by PECAM-1 and MMP-2. J Cell Biol 2003;160:605-615. [PubMed: 12591918]

28. Palmieri D, Lee J-W, Juliano RL, Church FC. Plasminogen Activator Inhibitor-1 and -3 Increase Cell Adhesion and Motility of MDA-MB-435 Breast Cancer Cells. J Biol Chem 2002;277:40950-40957. [PubMed: 12176977]

29. Whitley BR, Palmieri D, Twerdi C, Church FC. Expression of active plasminogen activator inhibitor-1 regulates cell migration and invasion in breast and gynecological cancer cells. Exp Cell Res 2004;296:151-162. [PubMed: 15149846]

30. Thellin O, Zorzi W, Lakaye B, De Borman B, Coumans B, Hennen G, Grisar T, Igout A, Heinen E. Housekeeping genes as internal standards: use and limits. J Biotechnol 1999;75:291-295. [PubMed: 10617337]

31. Kajanne R, Miettinen P, Mehlem A, Leivonen SK, Birrer M, Foschi M, Kahari VM, Leppa S. EGF$\mathrm{R}$ regulates MMP function in fibroblasts through MAPK and AP-1 pathways. J Cell Physiol 2007;212:489-497. [PubMed: 17348021]

32. Marinissen MJ, Servitja JM, Offermanns S, Simon MI, Gutkind JS. Thrombin protease-activated receptor-1 signals through Gq- and G13-initiated MAPK cascades regulating c-Jun expression to induce cell transformation. J Biol Chem 2003;278:46814-46825. [PubMed: 12954641] 
33. Ho TY, Bagnell CA. Relaxin induces matrix metalloproteinase-9 through activation of nuclear factor kappa B in human THP-1 cells. Ann N Y Acad Sci 2005;1041:314-316. [PubMed: 15956726]

34. Duxbury MS, Whang EE. RRM2 induces NF-kappaB-dependent MMP-9 activation and enhances cellular invasiveness. Biochem Biophys Res Commun 2007;354:190-196. [PubMed: 17222798]

35. Brown K, Gerstberger S, Carlson L, Franzoso G, Siebenlist U. Control of I kappa B-alpha proteolysis by site-specific, signal-induced phosphorylation. Science 1995;267:1485-1488. [PubMed: 7878466]

36. Domotor E, Benzakour O, Griffin JH, Yule D, Fukudome K, Zlokovic BV. Activated protein C alters cytosolic calcium flux in human brain endothelium via binding to endothelial protein $\mathrm{C}$ receptor and activation of protease activated receptor-1. Blood 2003;101:4797-4801. [PubMed: 12586611]

37. White B, Schmidt M, Murphy C, Livingstone W, O’Toole D, Lawler M, O'Neill L, Kelleher D, Schwarz HP, Smith OP. Activated protein C inhibits lipopolysaccharide-induced nuclear translocation of nuclear factor kappaB (NF-kappaB) and tumour necrosis factor alpha (TNF-alpha) production in the THP-1 monocytic cell line. Br J Haematol 2000;110:130-134. [PubMed: 10930989]

38. Cheng T, Liu D, Griffin JH, Fernandez JA, Castellino F, Rosen ED, Fukudome K, Zlokovic BV. Activated protein $\mathrm{C}$ blocks p53-mediated apoptosis in ischemic human brain endothelium and is neuroprotective. Nat Med 2003;9:338-342. [PubMed: 12563316]

39. Pianetti S, Arsura M, Romieu-Mourez R, Coffey RJ, Sonenshein GE. Her-2/neu overexpression induces NF-kappaB via a PI3-kinase/Akt pathway involving calpain-mediated degradation of IkappaB-alpha that can be inhibited by the tumor suppressor PTEN. Oncogene 2001;20:1287-1299. [PubMed: 11313873]

40. Zhou BP, Hu MC, Miller SA, Yu Z, Xia W, Lin SY, Hung MC. HER-2/neu blocks tumor necrosis factor-induced apoptosis via the Akt/NF-kappaB pathway. J Biol Chem 2000;275:8027-8031. [PubMed: 10713122]

41. Finco TS, Westwick JK, Norris JL, Beg AA, Der CJ, Baldwin AS Jr. Oncogenic Ha-Ras-induced signaling activates NF-kappaB transcriptional activity, which is required for cellular transformation. J Biol Chem 1997;272:24113-24116. [PubMed: 9305854]

42. Shibata M, Kumar SR, Amar A, Fernandez JA, Hofman F, Griffin JH, Zlokovic BV. Antiinflammatory, antithrombotic, and neuroprotective effects of activated protein $\mathrm{C}$ in a murine model of focal ischemic stroke. Circulation 2001;103:1799-1805. [PubMed: 11282913]

43. Mosnier LO, Griffin JH. Inhibition of staurosporine-induced apoptosis of endothelial cells by activated protein $\mathrm{C}$ requires protease-activated receptor-1 and endothelial cell protein $\mathrm{C}$ receptor. Biochem J 2003;373:65-70. [PubMed: 12683950]

44. Hurtado M, Lozano JJ, Castellanos E, Lopez-Fernandez LA, Harshman K, Martinez AC, Ortiz AR, Thomson TM, Paciucci R. Activation of the epidermal growth factor signalling pathway by tissue plasminogen activator in pancreas cancer cells. Gut 2007;56:1266-1274. [PubMed: 17452424]

45. Ortiz-Zapater E, Peiro S, Roda O, Corominas JM, Aguilar S, Ampurdanes C, Real FX, Navarro P. Tissue plasminogen activator induces pancreatic cancer cell proliferation by a non-catalytic mechanism that requires extracellular signal-regulated kinase $1 / 2$ activation through epidermal growth factor receptor and annexin A2. Am J Pathol 2007;170:1573-1584. [PubMed: 17456763]

46. Biscardi JS, Maa MC, Tice DA, Cox ME, Leu TH, Parsons SJ. c-Src-mediated phosphorylation of the epidermal growth factor receptor on Tyr845 and Tyr1101 is associated with modulation of receptor function. J Biol Chem 1999;274:8335-8343. [PubMed: 10075741]

47. Feistritzer C, Lenta R, Riewald M. Protease-activated receptors-1 and -2 can mediate endothelial barrier protection: role in factor Xa signaling. J Thromb Haemost 2005;3:2798-2805. [PubMed: 16359518]

48. Gschwind A, Hart S, Fischer OM, Ullrich A. TACE cleavage of proamphiregulin regulates GPCRinduced proliferation and motility of cancer cells. Embo J 2003;22:2411-2421. [PubMed: 12743035]

49. Schafer B, Marg B, Gschwind A, Ullrich A. Distinct ADAM metalloproteinases regulate G proteincoupled receptor-induced cell proliferation and survival. J Biol Chem 2004;279:47929-47938. [PubMed: 15337756]

50. Gooz M, Gooz P, Luttrell LM, Raymond JR. 5-HT2A receptor induces ERK phosphorylation and proliferation through ADAM-17 tumor necrosis factor-alpha-converting enzyme (TACE) activation 
and heparin-bound epidermal growth factor-like growth factor (HB-EGF) shedding in mesangial cells. J Biol Chem 2006;281:21004-21012. [PubMed: 16737974]

51. Sunnarborg SW, Hinkle CL, Stevenson M, Russell WE, Raska CS, Peschon JJ, Castner BJ, Gerhart MJ, Paxton RJ, Black RA, Lee DC. Tumor necrosis factor-alpha converting enzyme (TACE) regulates epidermal growth factor receptor ligand availability. J Biol Chem 2002;277:12838-12845. [PubMed: 11823465]

52. Hart S, Fischer OM, Prenzel N, Zwick-Wallasch E, Schneider M, Hennighausen L, Ullrich A. GPCRinduced migration of breast carcinoma cells depends on both EGFR signal transactivation and EGFRindependent pathways. Biol Chem 2005;386:845-855. [PubMed: 16164409]

53. Rodriguez-Viciana P, Warne PH, Dhand R, Vanhaesebroeck B, Gout I, Fry MJ, Waterfield MD, Downward J. Phosphatidylinositol-3-OH kinase as a direct target of Ras. Nature 1994;370:527-532. [PubMed: 8052307]

54. Nguyen M, Arkell J, Jackson CJ. Activated protein C directly activates human endothelial gelatinase A. J Biol Chem 2000;275:9095-9098. [PubMed: 10734039] 
A

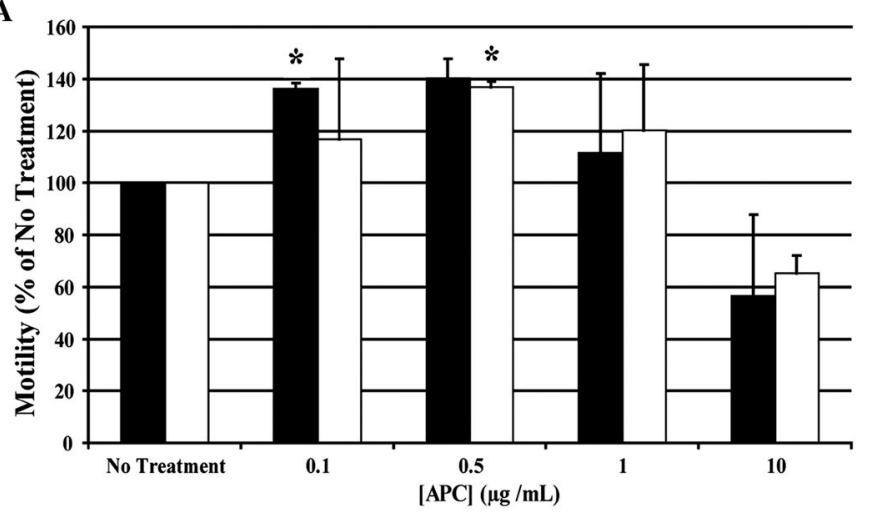

B

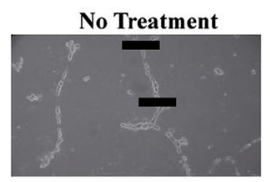

PC

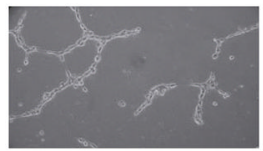

C
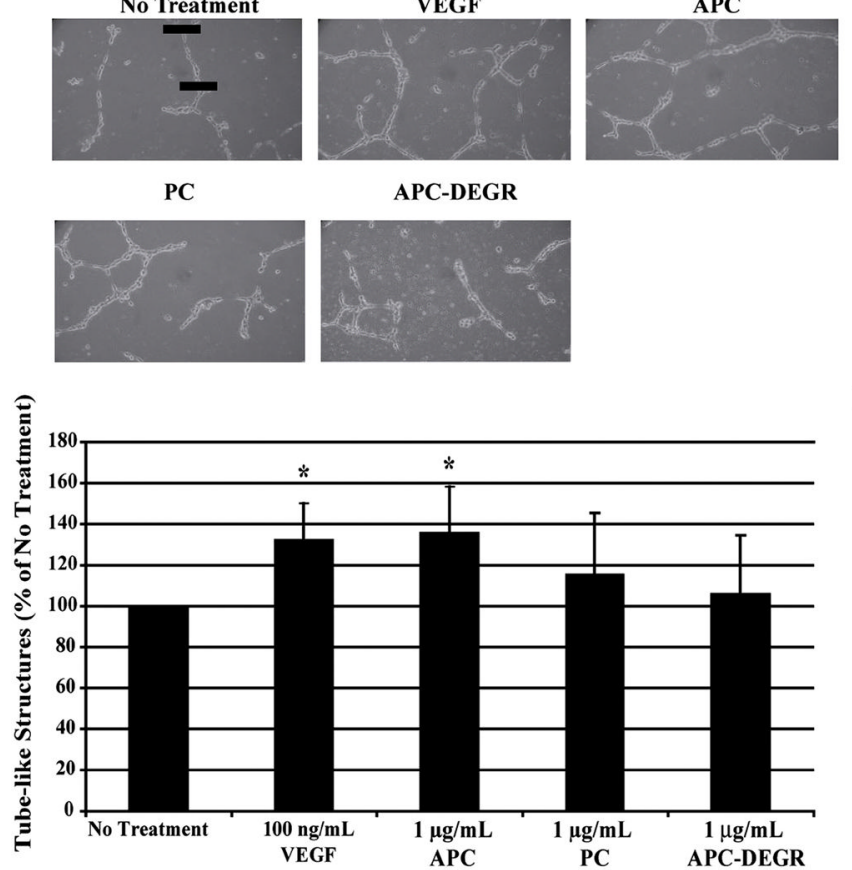

APC-DEGR

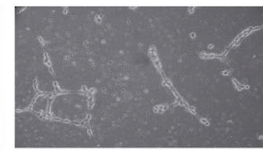

D

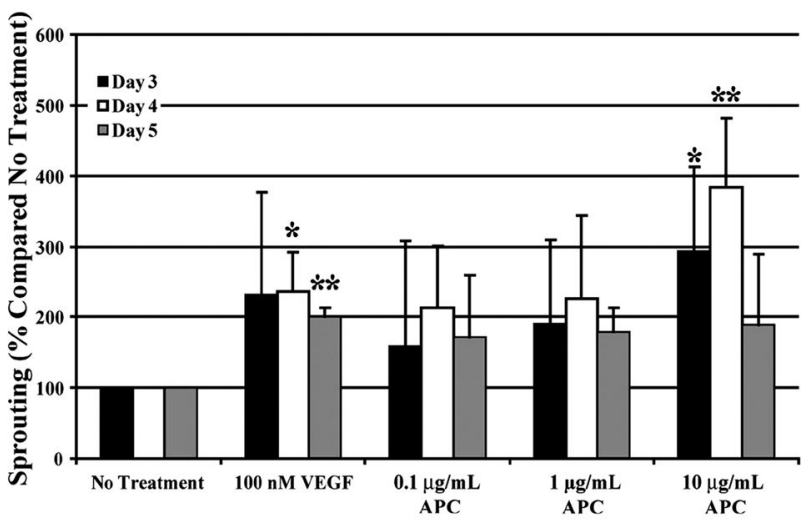

$\mathbf{E}$

$10 \mu \mathrm{g} / \mathrm{mL}$ APC

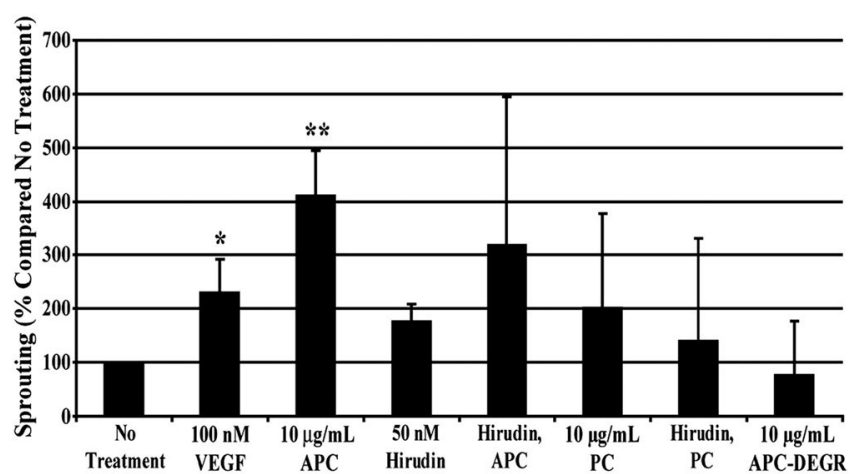

Figure 1. APC promotes HUVEC invasion, chemotaxis, tube formation and murine aortic ring sprouting

(A) HUVEC were treated with increasing concentrations of APC $(0-10 \mu \mathrm{g} / \mathrm{mL})$ for $24 \mathrm{~h}$, using $1 \mathrm{ng} / \mathrm{mL}$ VEGF as the chemotactic agent. Black bars are transwell invasion results and the white bars are chemotaxis results. (B) Representative photographs of HUVEC plated onto Growth Factor-Reduced Matrigel and treated with APC $(1 \mu \mathrm{g} / \mathrm{mL})$, PC $(1 \mu \mathrm{g} / \mathrm{mL})$, APC-DEGR $(1 \mu \mathrm{g} / \mathrm{mL}$ ), or VEGF (100 ng/mL; positive control) for $12 \mathrm{~h}$. (C) The number of tube-like structures (defined as 3 cells wide or less with junction points on both ends) were quantified at the $12 \mathrm{~h}$ time point. All graphs represent the average of 3 separate experiments. ${ }^{*} \mathrm{p}<0.05$ compared to No Treatment. (D) Murine aortic rings were treated with increasing concentrations of APC (1-10 $\mu \mathrm{g} / \mathrm{mL})$ or VEGF (100 $\mathrm{nM})$ for 5 days. On days 3-5, the number of sprouts projecting from the periphery of the aortic sections was counted. Graph represents the average of 4 separate experiments. ${ }^{*} \mathrm{p}<0.05,{ }^{*} \mathrm{p}<0.01$ compared to No Treatment. (E) Representative immunofluorescence staining of aortic rings for $\mathrm{vWF}$. (F) Murine aortic rings were treated with APC $(10 \mu \mathrm{g} / \mathrm{mL}) \pm$ hirudin $(50 \mathrm{nM})$, PC $(10 \mu \mathrm{g} / \mathrm{mL}) \pm$ hirudin $(50 \mathrm{nM})$, APC-DEGR $(10 \mu \mathrm{g} /$ $\mathrm{mL}$ ), or VEGF (100 nM) for 5 days. Graph represents the average of 2-3 separate experiments from data collected on day $4 . * \mathrm{p}<0.05, * * \mathrm{p}<0.01$ compared to No Treatment. 

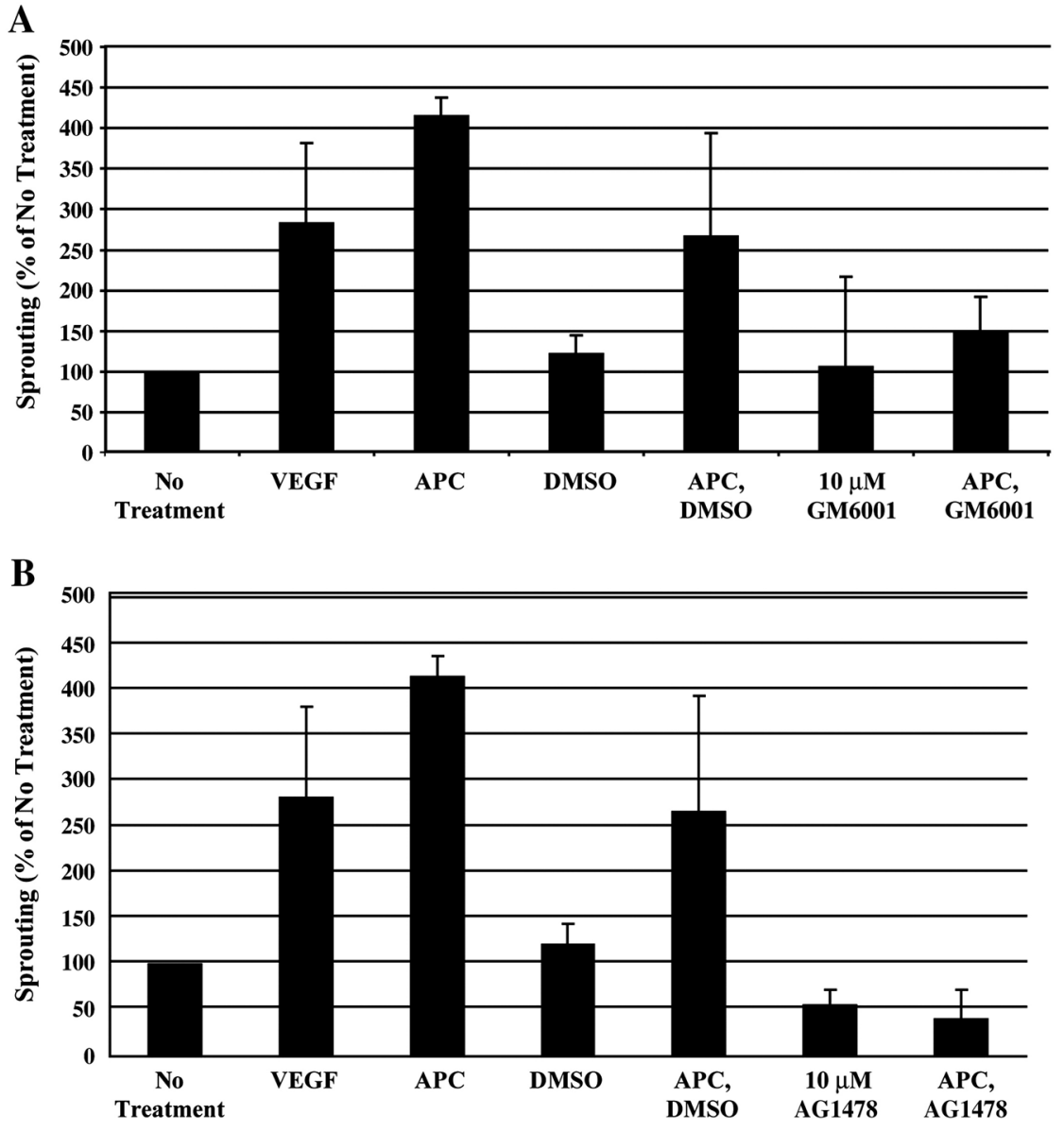

Figure 2. APC promotes sprout formation of murine aortic rings through MMPs and EGFR Murine aortic rings were pretreated on day 1 with $10 \mu \mathrm{M}$ of GM 6001 (A) or AG 1478 (B) for 30 minutes prior to the addition of APC $(10 \mu \mathrm{g} / \mathrm{mL})$. Graphs represent the average of 2 separate experiments from data collected on day 4. 
A

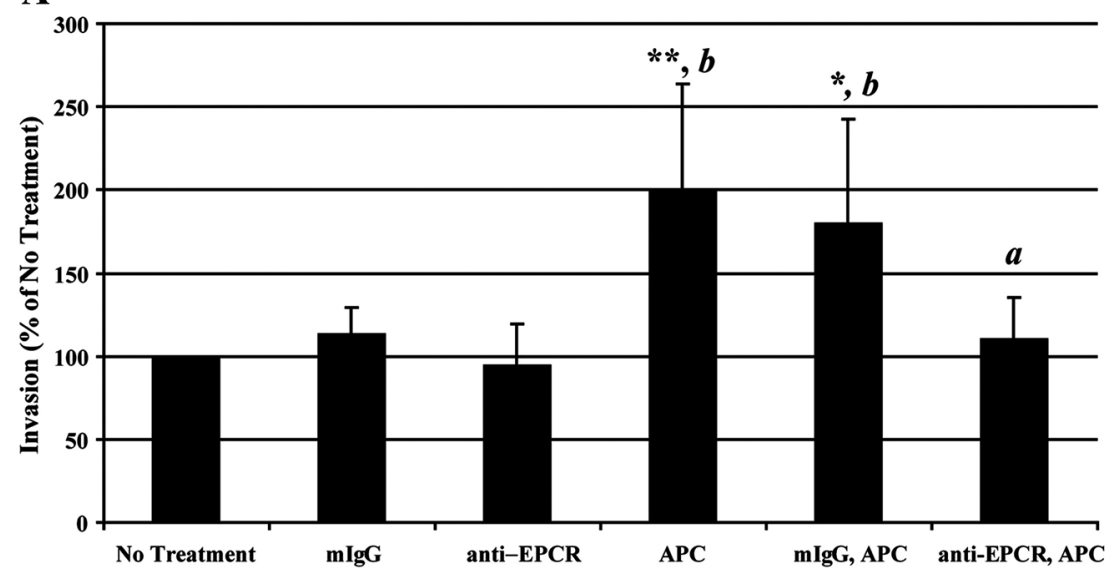

B

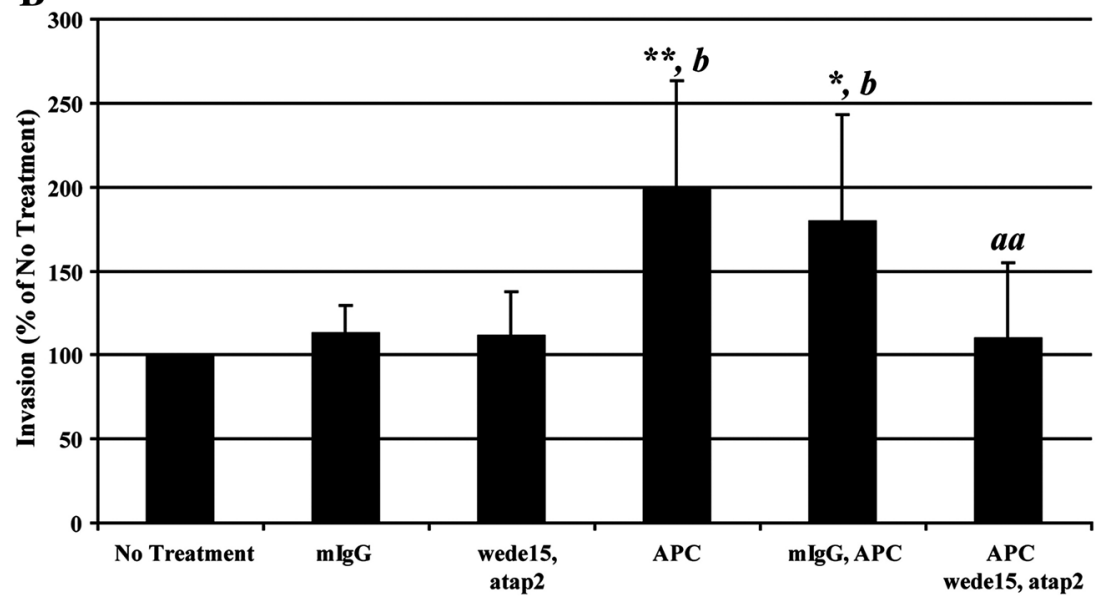

Figure 3. APC promotes invasion of the MDA-MB-231 cells by binding to EPCR and PAR-1 (A) Cells were pretreated with $4 \mu \mathrm{g} / \mathrm{mL}$ EPCR antibody (JNK 1494) or control mouse serum $\mathrm{IgG}$ for 15 minutes prior to the addition of $10 \mu \mathrm{g} / \mathrm{mL}$ APC. (B) In a separate experiment, cells were pretreated with $10 \mu \mathrm{g} / \mathrm{mL}$ atap 2 and $20 \mu \mathrm{g} / \mathrm{mL}$ wede 15 (PAR-1 blocking antibodies) or control mouse serum IgG for 15 minutes prior to the addition of $10 \mu \mathrm{g} / \mathrm{mL}$ APC. Cells invaded and migrated toward 10\% FBS containing media for $24 \mathrm{~h}$. The graphs represent the average of 8 separate experiments for both (A) and (B); $* \mathrm{p}<0.05$, ** $\mathrm{p}<0.01$ compared to No Treatment; $a \mathrm{p}<0.05, a a \mathrm{p}<0.01$ compared to APC treatment; $b \mathrm{p}<0.05$ compared to $\mathrm{mIgG}$ treatment. 
A
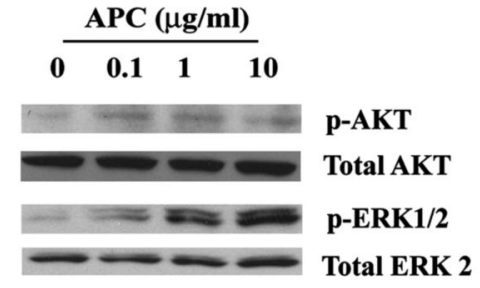

B

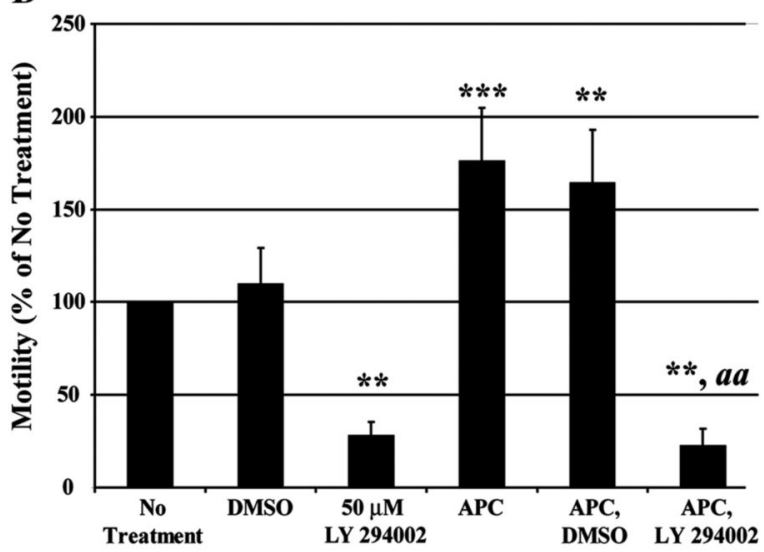

D

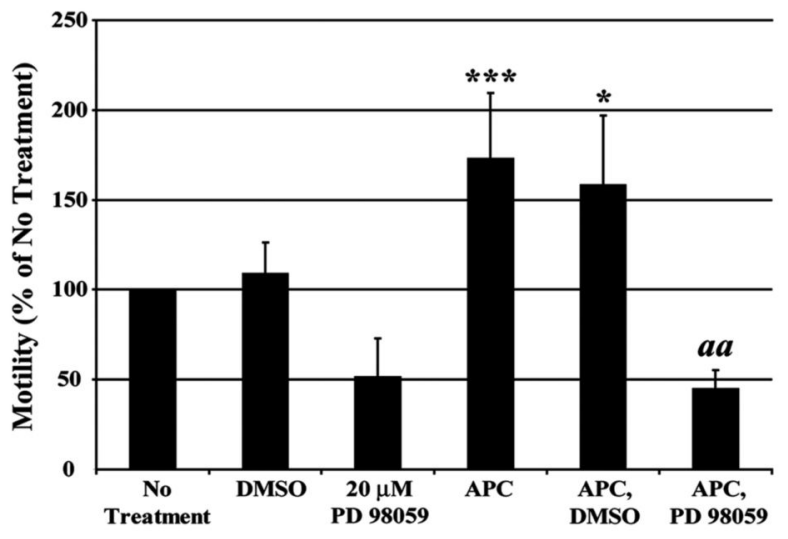

C

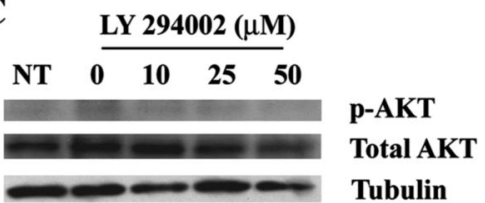

$\mathbf{E}$

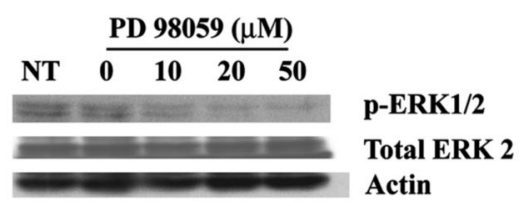

Figure 4. APC promotes chemotaxis of MDA-MB-231 cells by activating both the PI3K and MAPK pathways

(A) Cells were treated with increasing concentrations of APC $(0,0.1,1$, and $10 \mu \mathrm{g} / \mathrm{ml})$ for 24 $\mathrm{h}$ and cell lysates were immunoblotted for phosphorylated and total Akt, as well as phophorylated ERK1/2 and total ERK2. Additionally, cells were treated with increasing concentrations of (C) LY294002 (0-50 $\mu \mathrm{M})$ and (E) PD98059 (0-50 $\mu \mathrm{M})$, or (C and E) DMSO for $12 \mathrm{~h}$ to determine the optimal concentration of each inhibitor to be used in the transwell assay. Cells lysates were probed for phosphorylated and total Akt (C), phosphorylated ERK1/2 and ERK 2 (E), tubulin (C), and actin (E). Western blots shown are representative of 3 separate experiments. In $12 \mathrm{~h}$ transwell chemotaxis assay, cells were pretreated with $50 \mu \mathrm{M}$ LY 294002 (B) or $20 \mu \mathrm{M}$ PD 98059 (D) for 45 minutes prior to the addition of APC (10 $\mu \mathrm{g} / \mathrm{mL})$. Cells migrated toward $10 \%$ FBS containing media for $12 \mathrm{~h}$. Graphs represent the averages of 9 experiments for (B) and 8 experiments for (D). * $\mathrm{p}<0.05$, ** $\mathrm{p}<0.01$, *** $\mathrm{p}<0.001$ compared to No Treatment; a $\mathrm{p}<0.01$ compared to APC treatment. 
A

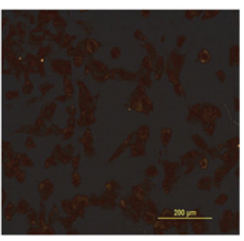

mIgG

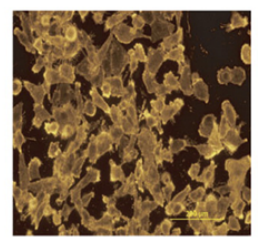

m-anti-EGFR

B

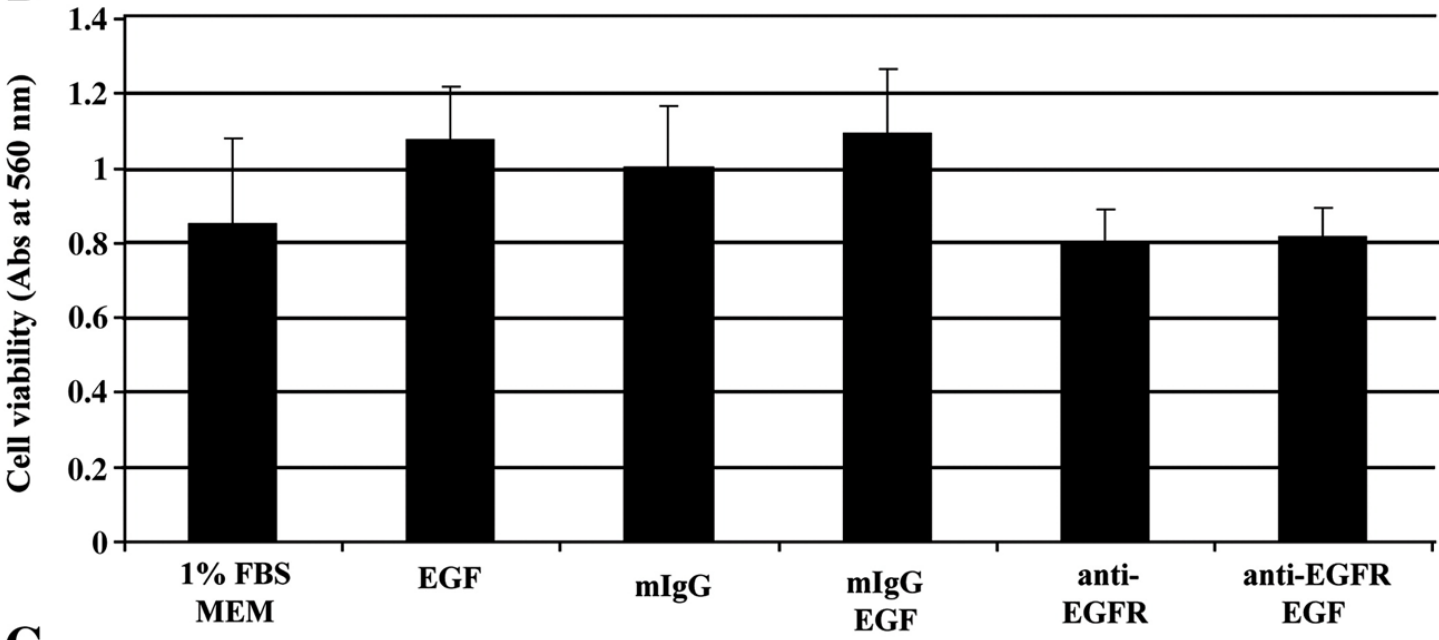

C



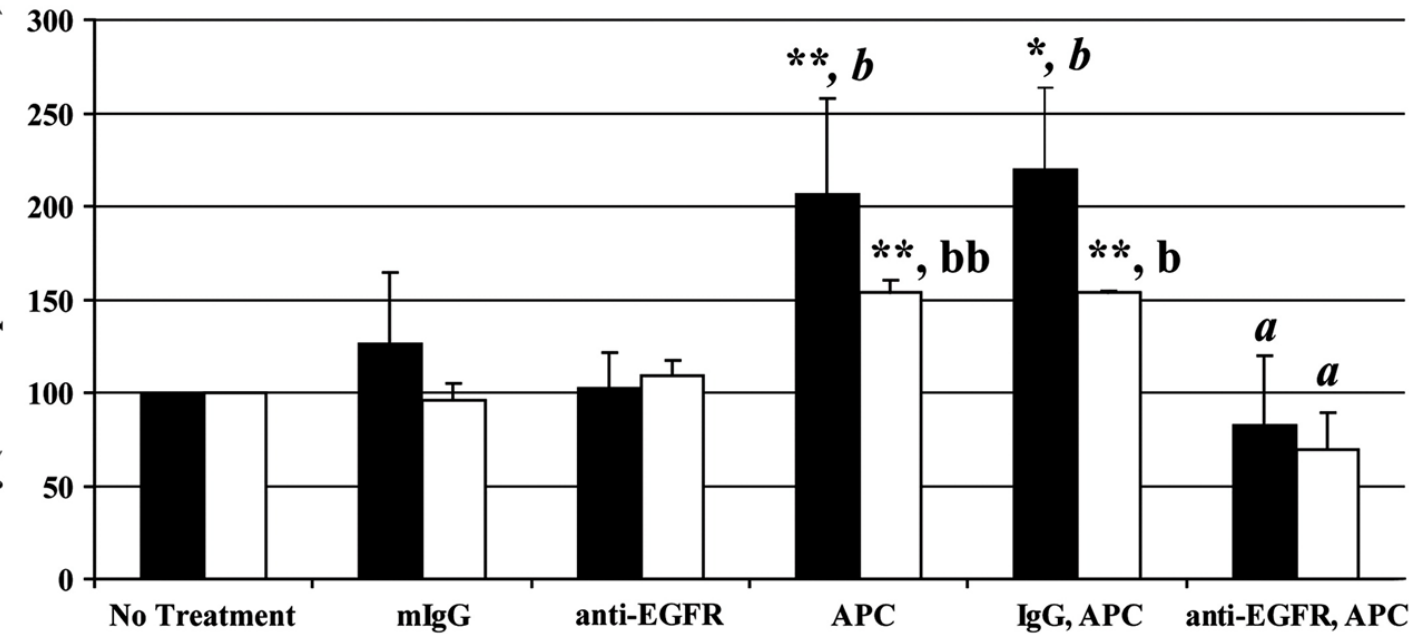

Figure 5. APC promoted invasion and chemotaxis of MDA-MB-231 cells is dependent upon qctivation of EGFR

(A) Immunofluorescence on the MDA-MB-231 cell monolayer for EGFR. (B) Cells were pretreated with EGFR antibody or control mouse serum $\operatorname{IgG}(20 \mu \mathrm{g} / \mathrm{mL})$ prior to the addition of $1 \mathrm{nM}$ EGF in SFM. Cells were allowed to grow for $48 \mathrm{~h}$ and then treated with MTT. Graphs represent the average absorbance for each condition for 4 separate experiments. (C) Cells were pretreated with $20 \mu \mathrm{g} / \mathrm{mL}$ anti-EGFR or control mouse serum IgG for 15 minutes prior to the addition of APC $(10 \mu \mathrm{g} / \mathrm{mL})$. Cells invaded for $24 \mathrm{~h}$ and chemotaxed for $12 \mathrm{~h}$ towards $10 \%$ FBS containing media. Graphs represent the average of 4 separate experiments for invasion and 3 separate experiments for chemotaxis assays; $* \mathrm{p}<0.05$, ** $\mathrm{p}<0.01$ compared to No 
Treatment; $a \mathrm{p}<0.05$ compared to APC treatment; $b \mathrm{p}<0.05, b b \mathrm{p}<0.01$ compared to $\mathrm{mIgG}$ treatment. 

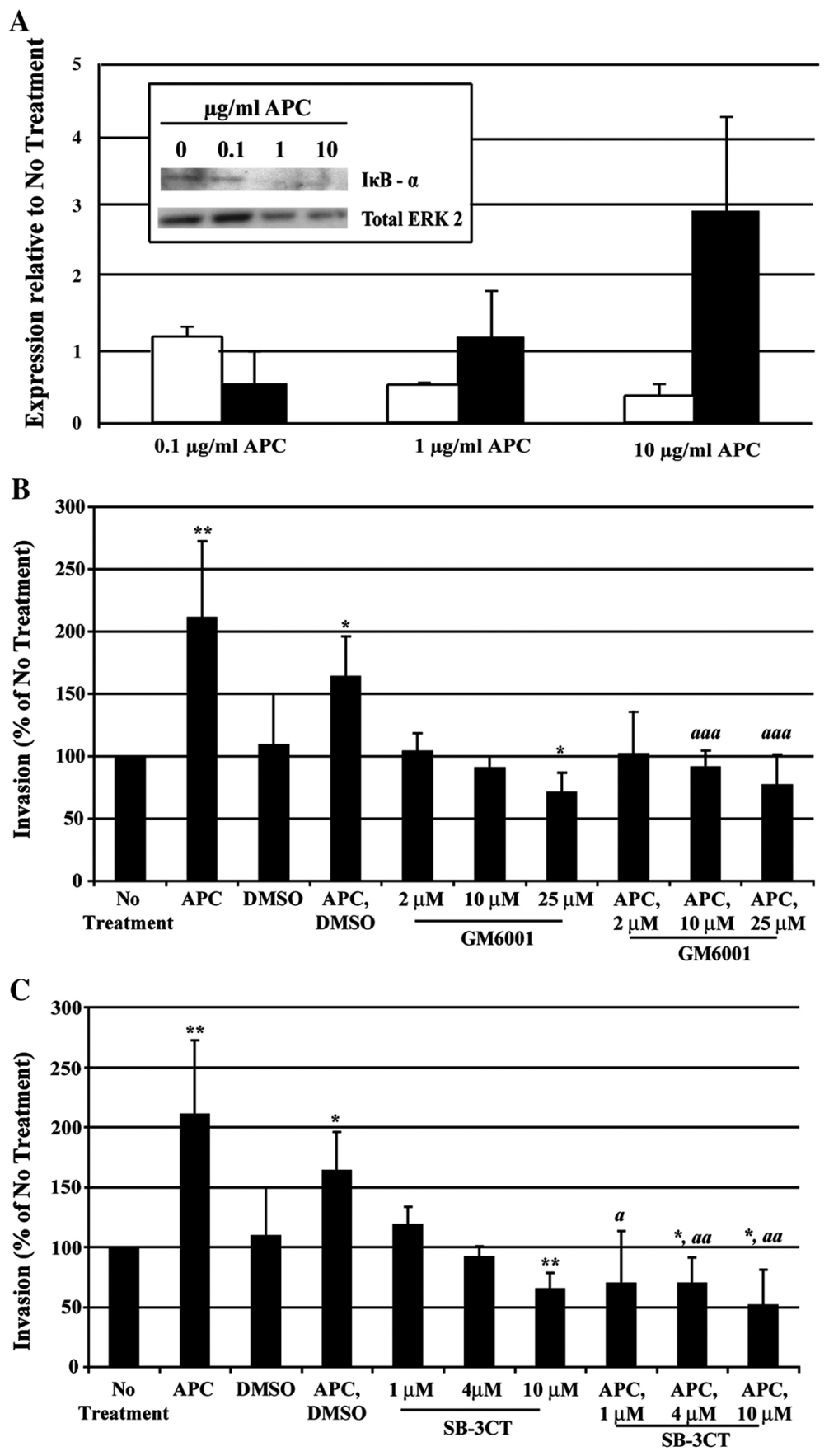

Figure 6. APC promoted invasion of MDA-MB-231 cells is dependent upon MMP-2 and MMP-9 degradation of the extracellular matrix

(A) Cells were treated with increasing concentrations of APC $(0.1,1$, and $10 \mu \mathrm{g} / \mathrm{ml})$ and assayed for MMP-2 and MMP-9 expression by quantitative PCR and NFאB activation by immunoblot of I $\kappa \mathrm{B}-\alpha$ (inset). For invasion assays, cells were pretreated with increasing concentrations of GM $6001(0-25 \mu \mathrm{M}$; B) or SB-3CT (0-10 $\mu \mathrm{M}$; C) for 15 minutes prior to the addition of 10 $\mu \mathrm{M}$ APC. Cells invaded towards $10 \%$ FBS containing media for $24 \mathrm{~h}$. Graphs represent the averages of 8 separate experiments; $* \mathrm{p}<0.05, * * \mathrm{p}<0.01$ compared to No Treatment; $a \mathrm{p}<0.05$, aa $\mathrm{p}<0.01$, aaa $\mathrm{p}<0.001$ compared to APC treatment. 

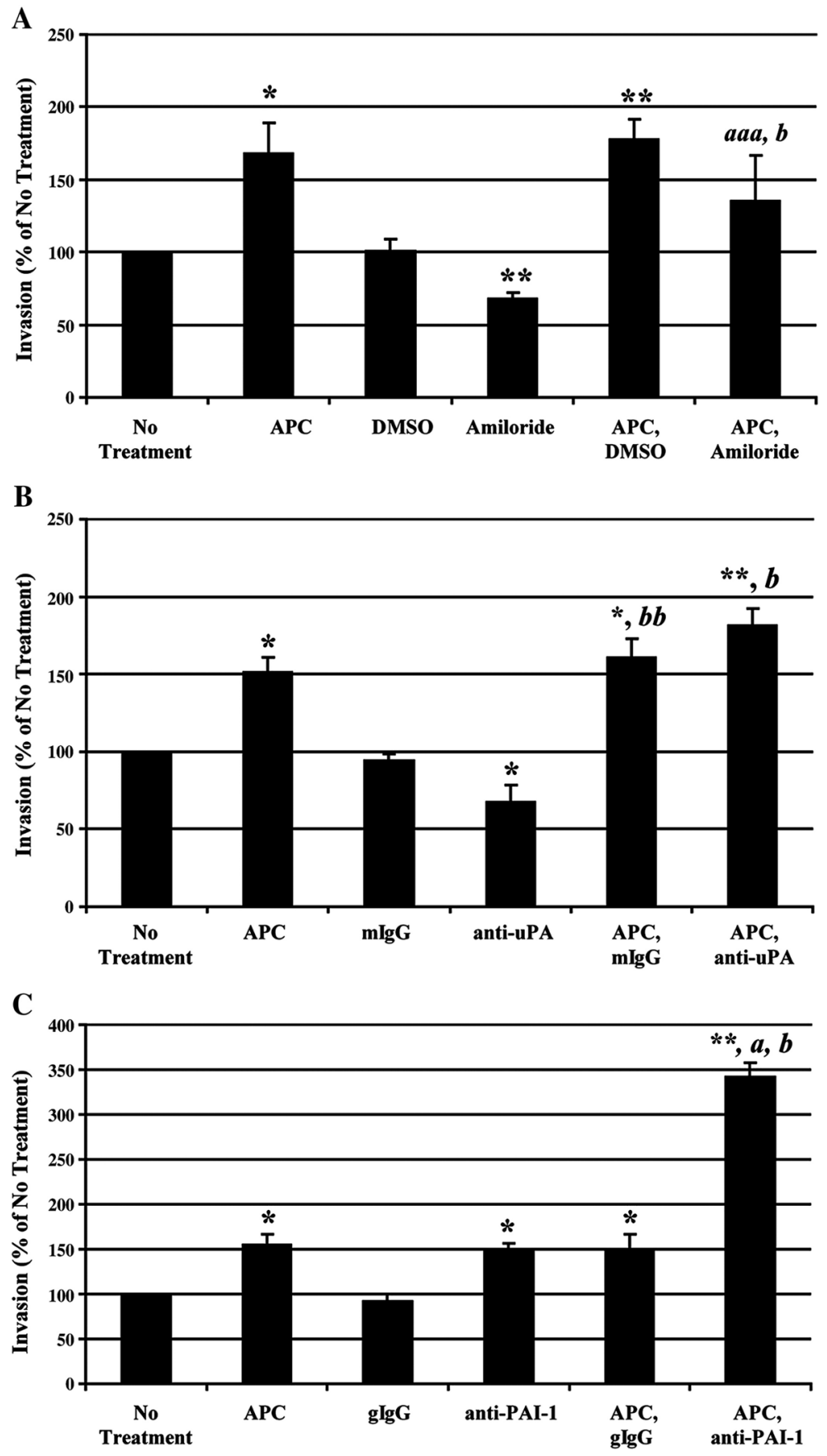

Figure 7. APC does not increase invasion of the MDA-MB-231 cells through the plasminogen activator system

Cells were pretreated with $0.2 \mathrm{mM}$ amiloride (A), $20 \mu \mathrm{g} / \mathrm{mL}$ anti-uPA (B), $20 \mu \mathrm{g} / \mathrm{mL}$ antiPAI-1 (C), and corresponding control antibodies for $1 \mathrm{~h}$ prior to the addition of $10 \mu \mathrm{g} / \mathrm{mL} \mathrm{APC}$. Cells invaded and migrated towards $10 \%$ FBS containing media for $24 \mathrm{~h}$. Graphs represent the average of 3 separate experiments; * $\mathrm{p}<0.05$, ** $\mathrm{p}<0.01$ compared to No Treatment; $a \mathrm{p}<0.05$, aaa $\mathrm{p}<0.001$ compared to APC treatment; $b \mathrm{p}<0.05, b b \mathrm{p}<0.01$ compared to amiloride/antiuPA/anti-PAI-1 treatment. 